\title{
Variability in yield of four grain legume species in a subhumid temperate environment I. Yields and harvest index
}

\author{
S. AYAZ, B. A. McKENZIE, G. D. HILL* AND D. L. MCNEIL† \\ Plant Sciences Group, Soil, Plant and Ecological Sciences Division, P.O. Box 84, Lincoln University, \\ Canterbury, New Zealand
}

(Revised MS received 5 January 2004)

\begin{abstract}
SUMMARY
In $1998 / 99$ and $1999 / 2000$, field trials were conducted to try to explain why grain legume yields and harvest index are more variable than many other crops. Treatments involved varying plant populations and sowing depths and were selected to maximize plant variability. Both yields and harvest index were variable. Total dry matter (TDM) production generally increased as plant population increased up to twice the optimum population. Increases ranged from 80 to $130 \%$ with lupins producing the highest yields of 878 and $972 \mathrm{~g} / \mathrm{m}^{2}$ of TDM in 1998/99 and 1999/2000 respectively. While plants sown at $10 \mathrm{~cm}$ depth produced more TDM than did plants sown at $2 \mathrm{~cm}$, the difference was only $3 \%$. Seed yields followed similar trends to TDM, with maximum yields (mean of $403 \mathrm{~g} \mathrm{seed} / \mathrm{m}^{2}$ ) produced at twice the optimum population. Crop harvest index $(\mathrm{CHI})$ was quite variable and ranged from 0.31 to $0 \cdot 66$. Crop HI was lowest $(0.43)$ at the lowest population and increased to 0.55 at twice the optimum plant population. In both seasons, lentil had the highest CHI and lupin the lowest. While CHI was variable there were very close relationships between seed yield and TDM which suggested that maximum seed yield depends on maximizing TDM production. The results also suggest that growers should increase population by a factor of two to obtain maximum seed yields.
\end{abstract}

\section{INTRODUCTION}

Grain legumes can produce high seed yields under favourable conditions (McKenzie \& Hill 1991; Moot 1997). However, yield instability within and between grain legume species at different sites and among seasons has been recognized as a persistent problem (Moot \& McNeil 1995; Ma et al. 1998), even when agronomic variation is minimized (Ambrose \& Hedley 1984). This yield instability has also been reported in Canterbury. Variation in harvest index (HI), which can lead to low average yields (Hedley \& Ambrose 1985), has been identified as the main cause (Moot \& McNeil 1995). To overcome the challenge of yield variability, breeders need to produce plants with high and stable yields that are adapted to diverse environments and are disease resistant (Moot \& McNeil

* To whom all correspondence should be addressed. Email: hill1@lincoln.ac.nz

$\uparrow$ Present address: DNRE, Victorian Institute for Dryland Agriculture, PMB 260, Horsham, Victoria 3401, Australia.
1995). Manipulating plant population and sowing pattern can reduce some of this variability. More uniform sowing may give less variable plant populations with reduced plant-to-plant variation and increased yield (Hedley \& Ambrose 1981).

Most grain legumes are reasonably plastic in their response to changed plant population. However, in many grain legumes the response to increased plant population has been variable. Seed yield, total dry matter (TDM) and HI of lentil (Lens culinaris), chickpea (Cicer arietinum), field pea (Pisum sativum) and faba bean (Vicia faba) all increased as plant population increased (Siddique \& Loss 1999). However, McKenzie et al. (1986) reported no yield increase in lentils as plant population increased from 100 to 400 plants $/ \mathrm{m}^{2}$, while HI was significantly reduced. Some researchers have reported optimum yield at equidistant inter- and intra-row spacings (Moot 1993). Variable HI is an important contributor to yield instability among grain legumes. Husain et al. (1988) and Anwar et al. (1999) reported HIs in grain legumes, which varied from $0 \cdot 00$ 
Table 1. MAF soil quick test for 0-30 cm depth for the Horticultural Research area (1998/99) and the Henley Research farm (1999/2000) of Lincoln University, Canterbury. $\mathrm{Ca}, \mathrm{K}, \mathrm{P}, \mathrm{Mg}, \mathrm{Na}$ and $\mathrm{S}$ and $\mathrm{NH}_{4}^{+}, \mathrm{NO}_{3}^{-}$are expressed as $\mu \mathrm{g} / \mathrm{g}$ soil, and total $N(T N)$ and $C$ as $\mathrm{g} / \mathrm{kg}$

\begin{tabular}{lcccccccccrr}
\hline \hline Season & $\mathrm{pH}$ & $\mathrm{Ca}$ & $\mathrm{K}$ & $\mathrm{P}$ & $\mathrm{Mg}$ & $\mathrm{Na}$ & $\mathrm{S}$ & $\mathrm{C}$ & $\mathrm{NH}_{4}^{+}$ & $\mathrm{NO}_{3}^{-}$ & $\mathrm{TN}$ \\
\hline $1998 / 99$ & $5 \cdot 4$ & 7 & 8 & 27 & 16 & 5 & 9 & $2 \cdot 4$ & - & 1 & $2 \cdot 0$ \\
$1999 / 2000$ & $5 \cdot 8$ & 10 & 9 & 12 & 28 & 8 & 9 & - & 5 & $<1$ & $2 \cdot 7$ \\
\hline \hline
\end{tabular}

to $0 \cdot 74$. Moot \& McNeil (1995) reported variable HIs in pea cultivars, which ranged from 0.53 to 0.62 in a single plant study.

Increased sowing depth may benefit crop establishment and performance because there is more available moisture in the subsoil. Alternatively, it may lead to increased variability in time to emergence. However, with the exception of Russell lupin (Lupinus arboreus $\times$ L. polyphyllus) (Wangdi et al. 1990), there is no published data on the effect of sowing depth on large-seeded legumes under field conditions in Canterbury. Deep sowing may help ensure good crop establishment (Stucky 1976). Sowing at $10 \mathrm{~cm}$ has been shown to increase seed yield in chickpea, faba bean, lentil and field pea (Saxena 1987; Siddique \& Loss 1999). In contrast, Wangdi et al. (1990) found no significant effect of sowing depth on early TDM production of Russell lupins, while Siddique et al. (1993) reported reduced yield with deep sowing in chickpea.

Vellasamy et al. (2000) and McKenzie et al. (1986) have shown that more than $27 \mathrm{t}$ of lupin TDM/ha and $13 \mathrm{t}$ of lentil TDM/ha can be produced under experimental conditions in Canterbury. McKenzie \& Hill (1995) reported experimental seed yields of more than $4 \mathrm{t} /$ ha from chickpea. Anwar et al. (1999) reported $12 \mathrm{t}$ $\mathrm{TDM} /$ ha with more than $6 \mathrm{t}$ seed/ha in Kabuli chickpea. Moot \& McNeil (1995) reported a TDM production of up to $12 \mathrm{t} /$ ha from field pea.

There is little published data on the effect of a combination of plant population and sowing depth on grain legume yield. Therefore, the present study was conducted to investigate whether agronomic practices such as plant population, sowing depth and their interaction had any impact on TDM, seed yield and HI in a range of grain legume species.

\section{MATERIALS AND METHODS}

\section{Grain legume species}

The four grain legume species selected were land race chickpea (Cicer arietinum), field pea (Pisum sativum) cv. Beacon, lentil (Lens culinaris) cv. Rajah and narrow-leafed lupin (Lupinus angustifolius) cv. Fest.

\section{Site and soil characteristics}

The experiment was located at the Horticultural Research Area in 1998/99 and at the Henley Research
Farm in 1999/2000. Both sites are at Lincoln University, Canterbury, New Zealand (latitude $43^{\circ} 39^{\prime} \mathrm{S}$, longitude $172^{\circ} 28^{\prime} \mathrm{E}$ ). The soil is a Wakanui silt loam soil (Hewitt 1992). A Chinese cabbage (Brassica campestris) crop had been grown in the previous season to the 1998/99 experiment, and the Henley site, used in $1999 / 2000$, was previously in perennial ryegrass (Lolium perenne). The climate data for the two experiments were recorded at Broadfield Meteorological station, Lincoln University, situated about $1 \mathrm{~km}$ from the experimental sites. A Ministry of Agriculture and Fisheries (MAF) soil quick test was done in each season to determine available soil nutrient levels (Table 1).

\section{Experimental design}

The first experiment (1998/99) was a split-plot randomized block design, with the four grain legume species (chickpea, lentil, narrow-leafed lupin and field pea) as main plots. Subplots consisted of four plant populations (one-tenth of the optimum population, the optimum population, twice the optimum population or four times the optimum population). Optimum plant populations were 50 plants $/ \mathrm{m}^{2}$ for chickpea, 150 plants $/ \mathrm{m}^{2}$ for lentil, 100 plants $/ \mathrm{m}^{2}$ for narrow-leafed lupin and 100 plants $/ \mathrm{m}^{2}$ for field pea. There were three replicates.

Each subplot was $10 \mathrm{~m}$ long and had 16 rows each $15 \mathrm{~cm}$ apart. Sowing was on 30 October 1998. Seed was sown at 4-5 cm depth using a tractor-driven cone seeder.

The second experiment (1999/2000) was a split splitplot design. The trial had the same four legume species as main plots. Subplots were three plant populations, and three sowing depths $(2,5$ or $10 \mathrm{~cm})$ were allocated to sub-subplots. There were three replicates.

Plots were hand sown, one replicate per 2 days between 19 and 24 October 1999 in equidistant arrangements. Sowing was on the square at $31 \cdot 5 \times 31 \cdot 5,10 \times$ 10 and $5 \times 5 \mathrm{~cm}$ to give plant populations of 10,100 and 400 plants $/ \mathrm{m}^{2}$. Each sub-subplot was $5.67 \times 3 \cdot 15$, $1.5 \times 2$ and $0.8 \times 0.2 \mathrm{~m}$ for the low, medium and high plant populations, respectively.

\section{Crop management}

Intensive crop management was used to minimize possible yield variation caused by agronomic factors. 
Table 2. Days from sowing to emergence of four grain legumes sown at three sowing depths and from sowing to harvest at three populations of four legume species sown in Canterbury, 1999/2000

\begin{tabular}{|c|c|c|c|c|c|c|}
\hline \multirow[b]{2}{*}{ Species } & \multicolumn{3}{|c|}{ Sowing depth $(\mathrm{cm})$} & \multicolumn{3}{|c|}{ Plant population (plants $/ \mathrm{m}^{2}$ ) } \\
\hline & 2 & 5 & 10 & 10 & 100 & 400 \\
\hline Chickpea & 7 & 8 & 11 & 159 & 154 & 150 \\
\hline Lentil & 7 & 9 & 11 & 136 & 132 & 128 \\
\hline Lupin & 6 & 9 & 14 & 168 & 163 & 159 \\
\hline Pea & 6 & 9 & 11 & 109 & 106 & 102 \\
\hline S.E. $($ D.F. $=48)$ & \multicolumn{3}{|c|}{$0 \cdot 3$} & \multicolumn{3}{|c|}{$0 \cdot 06$} \\
\hline
\end{tabular}

Prior to sowing, the fields were cultivated by ploughing, harrowing and rolling to produce high standard seedbeds. As well as a pre-sowing application of Treflan (trifluralin, $400 \mathrm{~g}$ a.i./1 in 237 litres of water/ ha) in the first experiment and of Round-up (glyphosate $360 \mathrm{~g}$ a.i./ 1 in 237 litres of water/ha) in the second experiment, a pre-emergence application of Bladex (cynazine $500 \mathrm{~g}$ a.i./1 in 237 litres of water/ha) was used in both trials. Gallant (haloxyfop, $100 \mathrm{~g}$ a.i./ 1 in 237 litres of water/ha) was used as a post-emergence spray for grass control. No weed control was necessary at the highest plant population. At lower plant populations weeds were controlled by hand hoeing.

No fertilizers were applied. Seed was treated with a fungicide, Apron 70 SD (metalaxyl 350 a.i. $/ \mathrm{kg}$ and captan $350 \mathrm{~g} / \mathrm{kg}$ ), at $200 \mathrm{~g}$ (dissolved in $500 \mathrm{ml}$ of water) per $100 \mathrm{~kg}$ seed.

Sprinklers were used to apply $75 \mathrm{~mm}$ of water in three irrigations each of $25 \mathrm{~mm}$ during the first experiment on 18 November and 30 December 1998 and 15 January 1999. In the second experiment, no irrigation was necessary due to adequate rainfall.

Mesurol (methiocarb, $750 \mathrm{~g}$ a.i./ $\mathrm{kg}$ in 200 litres of water) was sprayed onto the second trial to control bird attacks on the mature crops close to harvest.

\section{Measurements}

In the 1998/99 season, seed yield, TDM production and the crop harvest index (CHI; total seed yield per unit area divided by total yield per unit area) were calculated from a $2 \mathrm{~m}^{2}$ harvested area. This was taken randomly from four places using a $0.5 \mathrm{~m}^{2}$ quadrat along the central rows of each subplot at harvest maturity (when $95 \%$ of the plants within a species had turned brown). The four species (field pea, lentil, chickpea and narrow-leafed lupin) were harvested at $91,112,126$ and 133 days after sowing (DAS) respectively. Plants were cut to ground level, air dried and threshed in a Kurtpelz stationary thresher.

In 1999/2000, at crop maturity, a $0 \cdot 2 \mathrm{~m}^{2}$ area was cut to ground level. Because of differential maturity, plots were harvested on different days (Table 2). Samples were air-dried; pods were separated and bagged.
Samples were then oven dried at $70{ }^{\circ} \mathrm{C}$ to a constant weight and seed and straw was weighed.

All variates were analysed using analysis of variance procedures with the statistical programme Genstat (Genstat 5 Committee of the Statistics Department, Rothamsted Experimental Station, Hertfordshire, UK).

\section{RESULTS \\ Climate}

The weather from October 1998 to April 1999 was dry and the rainfall was about $40 \%$ less than the longterm average. Rainfall in October, November, December, January, February, March and April was 57, $20,24,36,38,56$ and $36 \mathrm{~mm}$, respectively, compared to 55 year corresponding mean values of $55,56,61$, $50,51,59$ and $52 \mathrm{~mm}$ (Fig. 1). Overall rainfall during the entire growing season (to $95 \%$ physiological maturity) was about $200 \mathrm{~mm}$.

Maximum and minimum temperatures were similar to the long-term average, but the mean temperature was increased by about $5 \%$ from January to March 1999. Solar radiation from January to March 1999 was also about $7 \%$ higher than the long-term average.

Rainfall from October 1999 to April 2000 was $353 \mathrm{~mm}$. This was about $90 \%$ of the long-term average of $385 \mathrm{~mm}$. Rainfall during the growing season (sowing to physiological maturity) was approximately $260 \mathrm{~mm}$. Maximum and minimum temperatures were similar to long-term averages (Fig. 1). However, mean monthly maximum temperatures during December 1999 to January 2000 were 18.9 and $19 \cdot 5^{\circ} \mathrm{C}$, respectively. These are lower than the 55 -year mean values of 21.3 and $22.6{ }^{\circ} \mathrm{C}$ respectively. Solar radiation from December 1999 to March 2000 was about $10 \%$ higher than the long-term mean.

\section{Emergence}

In the first trial, all species emerged $(>50 \%)$ by about 7-9 DAS. In the second trial, the species $\times$ depth interaction was highly significant $(P<0 \cdot 001)$, while population, species and/or their interaction were not 

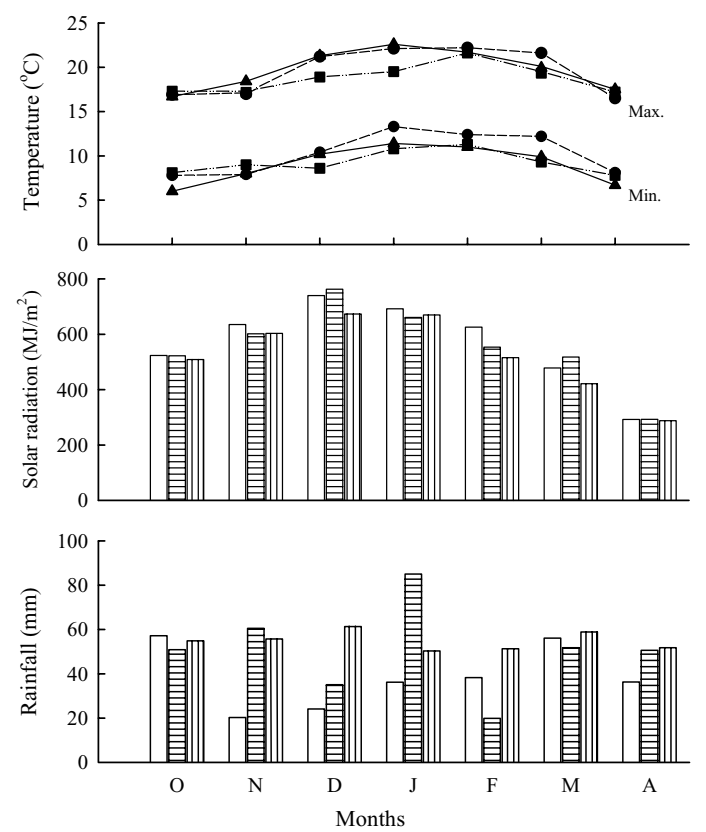

Fig. 1. Weather data for $1998 / 99(\square, \mathbf{0})$ and $1999 / 2000$ (E, $\bullet$ ) growing seasons and long-term means (III, $\mathbf{\Delta}$ ) for Lincoln University, Canterbury, New Zealand. Long-term means for rainfall and temperature (1944-99) and solar radiation (1975-99).

significant (Table 2). When sown at $2 \mathrm{~cm}$, lupin and pea emerged the fastest (6 DAS) and lentil and chickpea the slowest at 7 DAS. There was no difference in time of emergence from $5 \mathrm{~cm}$ depth. At the deepest sowing lupin was the last to emerge (14 DAS) and the other three species were the fastest (11 DAS).

\section{Total dry matter production}

In 1998/99, TDM production differed among both plant species and plant population (Table 3). Among the four species, the highest mean TDM production over all populations was $878 \mathrm{~g} / \mathrm{m}^{2}$ from lupin followed by chickpea at $701 \mathrm{~g} / \mathrm{m}^{2}$. The species by population interaction (Fig. 2a) showed that increased plant population increased TDM production in lentil and narrow-leafed lupin but decreased it in chickpea and field pea. For lentil and narrow-leafed lupin the lowest TDM (186 and $771 \mathrm{~g} / \mathrm{m}^{2}$, respectively) was at the lowest plant population (15 and 10 plants $/ \mathrm{m}^{2}$, respectively) and the highest TDM $\left(513\right.$ and $\left.971 \mathrm{~g} / \mathrm{m}^{2}\right)$ at the highest plant populations (600 and 400 plants $/ \mathrm{m}^{2}$, respectively). In chickpea and pea the lowest TDM yields ( 430 and $292 \mathrm{~g} / \mathrm{m}^{2}$, respectively) were also from the lowest plant populations ( 5 and 10 plants $/ \mathrm{m}^{2}$ ), but the highest TDM $\left(869\right.$ and $\left.670 \mathrm{~g} / \mathrm{m}^{2}\right)$ was produced at 100 and 200 plants $/ \mathrm{m}^{2}$, respectively.
Table 3. Total dry matter, seed yield and crop harvest index (CHI) of four legume species grown at different plant populations and sowing depths in Canterbury, 1998/99 and 1999/2000

\begin{tabular}{|c|c|c|c|}
\hline & $\begin{array}{l}\text { TDM } \\
\left(\mathrm{g} / \mathrm{m}^{2}\right) \\
\end{array}$ & $\begin{array}{c}\text { Seed } \\
\text { yield } \\
\left(\mathrm{g} / \mathrm{m}^{2}\right)\end{array}$ & $\mathrm{CHI}$ \\
\hline & $1998 / 99$ & & \\
\hline \multicolumn{4}{|l|}{ Species } \\
\hline Chickpea & 701 & 384 & $0 \cdot 52$ \\
\hline Lentil & 418 & 244 & $0 \cdot 57$ \\
\hline Lupin & 878 & 386 & $0 \cdot 44$ \\
\hline Pea & 532 & 286 & $0 \cdot 53$ \\
\hline S.E. (D.F. $=6)$ & $5 \cdot 0$ & $3 \cdot 8$ & $0 \cdot 008$ \\
\hline \multicolumn{4}{|l|}{ Population } \\
\hline One-tenth optimum & 420 & 173 & $0 \cdot 43$ \\
\hline Optimum & 664 & 340 & $0 \cdot 52$ \\
\hline Twice optimum & 738 & 403 & $0 \cdot 55$ \\
\hline Four times optimum & 708 & 384 & $0 \cdot 55$ \\
\hline S.E. (D.F. = 24) & $8 \cdot 3$ & $4 \cdot 7$ & $0 \cdot 010$ \\
\hline \multirow[t]{2}{*}{$\mathrm{CV} \%$} & $4 \cdot 5$ & $5 \cdot 1$ & $6 \cdot 1$ \\
\hline & $1999 / 2000$ & & \\
\hline \multicolumn{4}{|l|}{ Species } \\
\hline Chickpea & 800 & 458 & $0 \cdot 55$ \\
\hline Lentil & 468 & 293 & $0 \cdot 61$ \\
\hline Lupin & 972 & 527 & $0 \cdot 54$ \\
\hline Pea & 595 & 351 & $0 \cdot 58$ \\
\hline S.E. $($ D.F. $=6)$ & $7 \cdot 2$ & $5 \cdot 3$ & $0 \cdot 050$ \\
\hline \multicolumn{4}{|l|}{ Population } \\
\hline 10 plants $/ \mathrm{m}^{2}$ & 484 & 236 & $0 \cdot 50$ \\
\hline 100 plants $/ \mathrm{m}^{2}$ & 742 & 423 & $0 \cdot 58$ \\
\hline 400 plants $/ \mathrm{m}^{2}$ & 900 & 563 & $0 \cdot 63$ \\
\hline S.E. (D.F. = 16) & $3 \cdot 7$ & $2 \cdot 8$ & $0 \cdot 004$ \\
\hline \multicolumn{4}{|l|}{ Sowing depth } \\
\hline $2 \mathrm{~cm}$ & 696 & 394 & $0 \cdot 56$ \\
\hline $5 \mathrm{~cm}$ & 711 & 407 & $0 \cdot 57$ \\
\hline $10 \mathrm{~cm}$ & 720 & 420 & $0 \cdot 58$ \\
\hline S.E. (D.F. $=48$ ) & $1 \cdot 8$ & $1 \cdot 6$ & $0 \cdot 003$ \\
\hline $\mathrm{CV} \%$ & $1 \cdot 5$ & $2 \cdot 4$ & $3 \cdot 4$ \\
\hline
\end{tabular}

In 1999/2000, TDM production was significantly influenced by legume species, plant population and sowing depth (Table 3). Averaged over both seasons the highest population density produced $80 \%$ more TDM than the lowest population. Total DM production ranged from $595 \mathrm{~g} / \mathrm{m}^{2}$ in lentil to $972 \mathrm{~g} / \mathrm{m}^{2}$ in narrow-leafed lupin. The plant population by species interaction was significant $(P<0 \cdot 05)$ (Fig. $2 b)$. It showed that lentil TDM had the highest percentage variation over the three populations. There was nearly a $200 \%$ increase in TDM from 10 to 400 plants $/ \mathrm{m}^{2}$. In narrow-leafed lupins, however, the increase in TDM production between 10 and 400 plants $/ \mathrm{m}^{2}$ was only $35 \%$. The other two species had intermediate values. The significant species by sowing depth interaction 

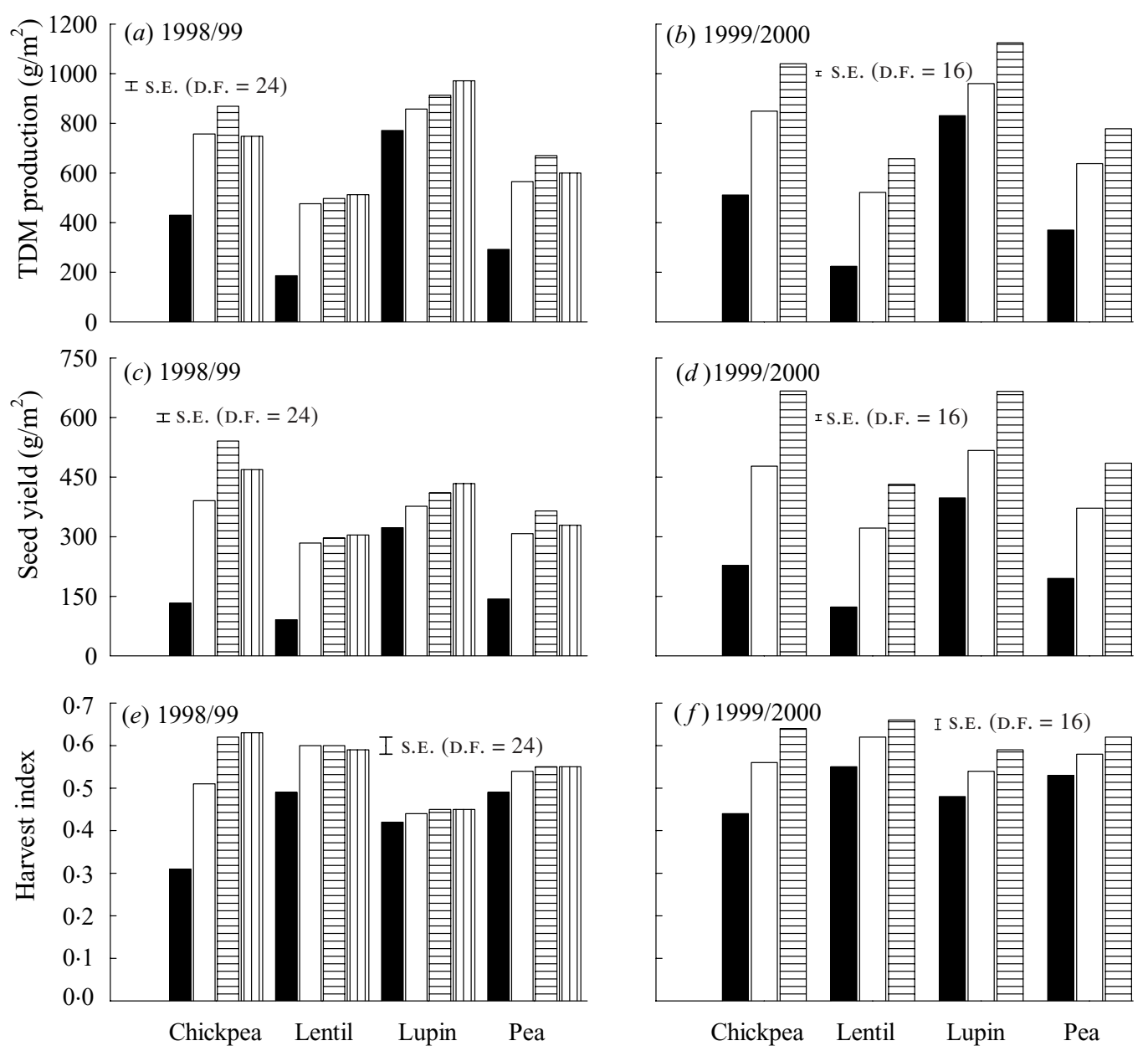

Legume species

Fig. 2. The interaction between crop population and four grain legume species on yield and crop harvest index in Canterbury, $1998 / 99(a, c, e)$; one-tenth of the optimum population ( $\square$ ), the optimum population ( $\square$ ), twice the optimum population (E), four times the optimum population (III), and 1999/2000 (b,d,f);10 plants $/ \mathrm{m}^{2}(\boldsymbol{\square}), 100$ plants $/ \mathrm{m}^{2}(\square), 400 \mathrm{plants} / \mathrm{m}^{2}(巨)$ ).

(Table 3) indicated that as sowing depth increased from 2 to $10 \mathrm{~cm}$, there was a very small increase in TDM production in narrow-leafed lupin. However, the response in lentil was larger at about $8 \%$. The TDM at final harvest over the two seasons ranged from $418-972 \mathrm{~g} / \mathrm{m}^{2}$. In $1999 / 2000$ the species produced about $20 \%$ more TDM, on average, than in 1998/99.

\section{Seed yield}

In 1998/99, seed yield was significantly affected by both species and population, and their interactions. Chickpea and narrow-leafed lupin yielded more than lentil and field pea (Table 3). The species by population interaction (Fig. $2 c$ ) showed that only lentils and narrow-leafed lupin increased their seed yield (from 91 to 304 and 323 to $434 \mathrm{~g} / \mathrm{m}^{2}$, respectively) as plant population increased from 15 to 600 and 10 to 400 plants $/ \mathrm{m}^{2}$, respectively. Chickpea and field pea produced their highest seed yield (541 and $365 \mathrm{~g} / \mathrm{m}^{2}$ ) when sown at 100 and 200 plants $/ \mathrm{m}^{2}$, respectively. At the highest plant density seed yield declined in both species.

In 1999/2000, as in 1998/99, chickpea and narrowleafed lupin out-yielded lentil and field pea (Table 3). The species by plant population interaction (Fig. 2d) showed that lentil seed yield varied most across populations. Seed yield increased from 123 to $432 \mathrm{~g} / \mathrm{m}^{2}$, an increase of $250 \%$, as plant population increased from 10 to 400 plants $/ \mathrm{m}^{2}$. In narrow-leafed lupin, seed yield was not affected by increased sowing depth, but 
Table 4. The species by sowing depth interaction for TDM production $\left(\mathrm{g} / \mathrm{m}^{2}\right)$ and seed yield $\left(\mathrm{g} / \mathrm{m}^{2}\right)$ in Canterbury, 1999/2000

\begin{tabular}{|c|c|c|c|c|c|c|}
\hline \multirow[b]{3}{*}{ Species } & \multicolumn{3}{|c|}{ TDM production } & \multicolumn{3}{|c|}{ Seed yield } \\
\hline & \multicolumn{6}{|c|}{ Sowing depth $(\mathrm{cm})$} \\
\hline & 2 & 5 & 10 & 2 & 5 & 10 \\
\hline Chickpea & 788 & 802 & 810 & 443 & 455 & 475 \\
\hline Lentil & 447 & 469 & 487 & 276 & 291 & 310 \\
\hline Lupin & 968 & 973 & 976 & 518 & 530 & 533 \\
\hline Pea & 580 & 599 & 607 & 338 & 352 & 362 \\
\hline S.E. (D.F. $=48)$ & \multicolumn{3}{|c|}{$7 \cdot 8$} & \multicolumn{3}{|c|}{$6 \cdot 0$} \\
\hline
\end{tabular}

lentil yield increased significantly $(P<0.001)$ from shallow to deep sowing by $12 \%$ (Table 4 ). The other two species were intermediate to these values. Overall the $1999 / 2000$ growing season yielded $25 \%$ more seed than the 1998/99 season.

\section{Crop harvest index}

In 1998/99, crop harvest index (CHI) was significantly affected $(P<0 \cdot 001)$ by both species and plant population (Table 3). Averaged over all populations lentil had the highest CHI (0.57) and narrow-leafed lupin the lowest $(0 \cdot 44)$. The species by population interaction (Fig. $2 e$ ) shows that the CHI for the four species increased between the low and medium populations. At high populations, however, there was only a yield increase in chickpea. The highest CHIs $(0.62$ and $0 \cdot 63)$ were recorded in chickpeas sown at the high (100 plants $/ \mathrm{m}^{2}$ ) and very high plant populations (200 plants $\left./ \mathrm{m}^{2}\right)$.

In 1999/2000, CHI was higher than in 1998/99. Lentil and narrow-leafed lupin increased their respective CHIs by 7 and $23 \%$ between the two seasons from 0.57 to 0.61 and 0.44 to 0.54 , respectively. In chickpea, the increase was greater over the three populations (Fig. 2f). The increase in CHI between 10 and 400 plants $/ \mathrm{m}^{2}$ was from 0.44 to $0 \cdot 64$, respectively. For field pea, however, the increase in $\mathrm{CHI}$ from the low to high populations was from 0.53 to $0 \cdot 62$.

There was a positive, linear and highly significant $(P<0 \cdot 01)$ relationship between TDM and seed yield (Fig. 3). The regression coefficients were greater than 0.95 in both trials.

\section{DISCUSSION}

In the present study, both TDM and seed yield at final harvest were influenced by both legume species and plant population. There were very high correlations $\left(R^{2}>0.95\right)$ between seed yield and TDM in all four species in both growing seasons. Thus high DM pro- duction contributed to higher seed yield. High TDM production is a prerequisite for high seed yield in chickpea (Saxena 1987; Siddique et al. 1993; Omar \& Singh 1997), pinto bean (Phaseolus vulgaris; Dapaah et al. 2000) and Vicia faba and peas (Thomson et al. 1997).

Species differences in TDM production depended on growth duration. Lupin and chickpea had much longer durations than pea or lentil. The former two species intercepted more light and had delayed senescence. This resulted in more TDM production. The extra yield may also have been due to differences in the radiation use efficiency (RUE) among these species (Ayaz et al., in press). Similar results were reported for Lupinus mutabilis and pinto beans (Hardy et al. 1996; Dapaah 1997), respectively.

In the present study, the species $\times$ population interaction for TDM production was significant as it increased from low to high plant populations. High plant populations close their canopies quickly and intercept more sunlight more rapidly than low plant populations (McKenzie \& Hill 1991; Hardy et al. 1996). This results in high early crop growth rates, which can be sustained if the crops have adequate soil moisture and fertility. Only in narrow-leafed lupin, which had a very long growth duration, did the low plant population yield nearly as much as at the highest population (Ayaz et al. 1999). This was again related to increased radiation interception, as the low population lupin plants produced extensive basal branches which helped increase radiation interception.

Averaged over all species TDM production was $40 \%$ higher in $1999 / 2000$ than in $1998 / 99$. This might have been due to the lower temperatures in 1999/2000, which lengthened crop duration in all four species (Saxena \& Goldsworthy 1988). There was also more rainfall. In Western Australia, in a high rainfall year, legume species also responded by increasing yield (Thomson et al. 1997).

Increasing the sowing depth increased TDM and seed yield in all four species in the present study. Similar results have been reported for chickpea, faba bean, lentil and pea (Saxena 1987; French \& Pritchard 1993; Siddique \& Loss 1999). The increased yield from sowing at depth was probably due to greater moisture availability in the subsoil (Siddique \& Loss 1999).

The regressions of TDM against $\log _{(\mathrm{e})}$ (population) indicated a high degree of linearity. The slopes and regression coefficients are presented in Table 5 . When the slopes of the regressions are compared, chickpea was most responsive and narrow-leafed lupin the least. Narrow-leafed lupin had a very long crop duration and most growth occurred after canopy closure, irrespective of plant population. Consequently, they were less responsive to population density than the other three species.

Highest seed yields were from narrow-leafed lupin followed by chickpea. Lentil had the lowest seed yield. 


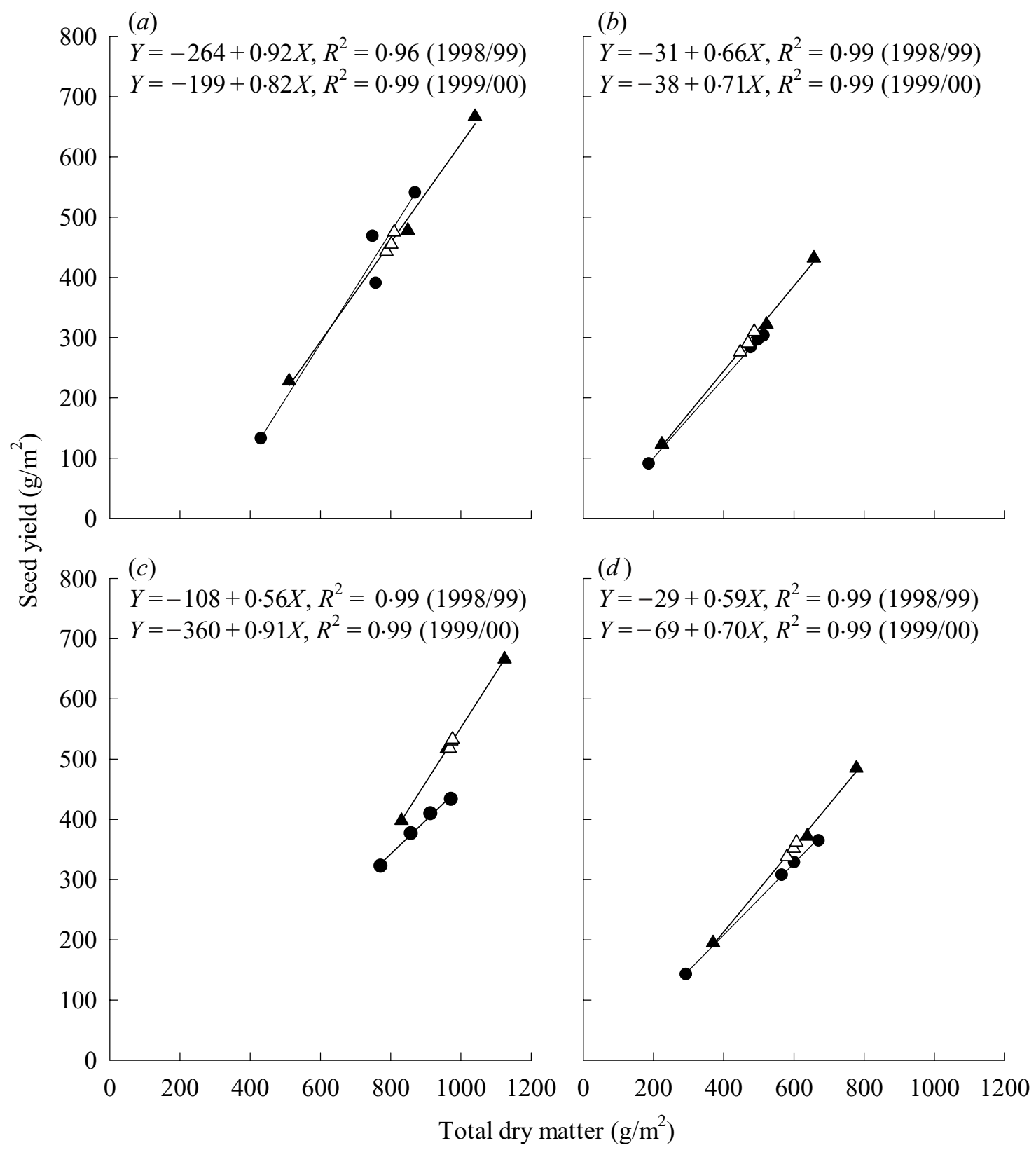

Fig. 3. The relationship between seed yield and total dry matter production at final harvest for $(a)$ chickpeas, $(b)$ lentils, (c) lupins, $(d)$ peas sown at four plant populations (O) in 1998/99, and three plant populations $(\boldsymbol{\Delta})$ and three sowing depths $(\triangle)$ in $1999 / 2000$.

Lentil plants are smaller and more determinate in their growth habit than chickpea and other legumes (Erskine \& Goodrich 1991). Their capacity to compensate for low plant population by producing more branches and pods/plant is less than in lupin, chickpea and pea. Although a greater number of pods/plant was produced at the low population of lentils (Ayaz et al. 2004) the increase was not enough to compensate for the low plant density and seed yield was reduced at the low population. Silim et al. (1990) advocated that a high plant population was necessary for high seed yield and TDM production in lentil. 
Table 5. Gradients (b) and regressions ( $\mathrm{R}^{2}$; \%) for plots of species v. log (e) plant population, 1998/99 and $1999 / 2000$

$1998 / 99$

$1999 / 2000$

\begin{tabular}{|c|c|c|c|c|c|c|c|c|c|c|c|c|}
\hline \multirow[b]{2}{*}{ Species } & \multicolumn{2}{|c|}{$\mathrm{TDM}^{*}$} & \multicolumn{2}{|c|}{ SY } & \multicolumn{2}{|c|}{$\mathrm{CHI}$} & \multicolumn{2}{|c|}{ TDM } & \multicolumn{2}{|c|}{ SY } & \multicolumn{2}{|c|}{ CHI } \\
\hline & $\mathrm{b}$ & $R^{2}$ & b & $R^{2}$ & b & $R^{2}$ & b & $R^{2}$ & b & $R^{2}$ & $\mathrm{~b}$ & $R^{2}$ \\
\hline Chickpea & 105 & 79 & 105 & 89 & $0 \cdot 10$ & 97 & 143 & 99 & 118 & 99 & $0 \cdot 10$ & 99 \\
\hline Lentil & 94 & 93 & 61 & 92 & 0.03 & 82 & 118 & 99 & 84 & 99 & 0.03 & 99 \\
\hline Lupin & 52 & 95 & 30 & 98 & $0 \cdot 01$ & 97 & 77 & 96 & 70 & 96 & $0 \cdot 03$ & 99 \\
\hline Pea & 97 & 87 & 58 & 88 & $0 \cdot 02$ & 95 & 111 & 99 & 78 & 99 & 0.02 & 99 \\
\hline
\end{tabular}

* $\mathrm{TDM}=$ total dry matter, $\mathrm{SY}=$ seed yield, $\mathrm{CHI}=$ crop harvest index.

High seed yields were also the result of high TDM production in the present study and yields were $25 \%$ higher in $1999 / 2000$. This was caused by the cooler wetter conditions in 1999/2000 which resulted in longer crop durations, increased radiation interception and in greater yields. The equidistant sowing of the crops may have contributed to the higher yields observed in 1999/2000. When two plants compete, the outcome is 'one-sided', i.e. the relative growth rate of the smaller plants is decreased while the larger plant is unaffected. Weiner et al. (1990) also suggested that this asymmetry is primarily due to competition for light and soil resources. Several other workers have reported optimum yields at equidistant inter- and intrarow spacings (Parvez et al. 1989). In the present study, competition was high within a row for rectangular sown plants compared with on-the-square sown plants, where the competition was low and slower to develop for light and nutrients. In the rectangular sowing, larger plants met and shaded smaller plants quickly. Similarly, below-ground competition for nutrients would have been greater in the rectangular sowings.

Overall, seed yield approximately doubled as plant population increased from one-tenth of the optimum to the optimum in 1998/99 and from 10 to 100 plants/ $\mathrm{m}^{2}$ in $1999 / 2000$. However, with an additional fourfold increase in plant population, the species did not respond in the same way and yield only increased by about $30 \%$ in 1999/2000. In 1998/99, increasing population density from one-tenth of the optimum to the optimum increased seed yield while at the four-fold population increase there was a yield plateau. This may have been associated with reduced branching and slower leaf formation at the highest population (Stern 1965). At very high plant populations, competition develops earlier and becomes progressively more intense. If the population is sufficiently high, some plants will die as shading reduces their capacity to exploit nutrient supply and competition develops for nutrients as well as for light (Stern 1965). Moot (1993) also reported an asymptotic relationship in peas as plant population was increased. The increase in seed yield with increased plant population, up to 400 plants $/ \mathrm{m}^{2}$ in all species, during the $1999 / 2000$ trial is supported by the results of Effendi et al. (1989) and McKenzie et al. (1989) with lentil. Increasing plant population from 10 to 100 plants $/ \mathrm{m}^{2}$, almost doubled seed yield. However, further increase in plant population only increased the yield by $30 \%$. Moot (1993) reported similar results for peas in Canterbury.

Seed yield in chickpea responded strongly to increased plant population while narrow-leafed lupin responded the least (Table 5). The effect of plant population on seed yield is consistent with other published data (Pilbeam et al. 1991; Ayaz et al. 1999). In the present study, seed yield of legume species continued to increase from one-tenth of the optimum to four times the optimum plant population except in chickpea and field pea in which yield declined at the highest population. In 1998/99, lentil seed yield tended to increase up to 600 plants $/ \mathrm{m}^{2}$. Moot \& McNeil (1995) reported that, in their experiments, seed yield of some pea cultivars had an asymptotic response to increased plant population while others exhibited a parabolic response. This indicates that maximum seed yield might be produced beyond the populations tested. In the present study, however, there was only a small increase in seed yield as plant population was increased from the optimum to four times the optimum. This may result in an economic loss through increased seed costs needed to maximize seed yield.

In the present study, the CHI was variable over species, populations and sowing depths. Averaged over all treatments, the highest CHI was in lentil and the lowest in lupin, in both seasons. This may have been due to the shorter lentil stems. In cereal crops, improvements in HI have generally been made through a reduction in stem length and the increased diversion of assimilates to grain production (Stanforth et al. 1994). This variation in CHI may also have been due to the conversion of a higher proportion of the dry matter of the lentil to seed than in narrowleafed lupin, which consequently gave a higher $\mathrm{CHI}$ as Moot (1993) reported in different pea genotypes. Also 
in a range of grain legumes, chickpea (0.42), common vetch (0.44) (Siddique et al. 1999), lentil (0.50) and faba bean $(0.55)$ tended to have higher HIs than $L$. angustifolius $(0 \cdot 25)$ L. albus $(0 \cdot 21)$ (Thomson et al. 1997). Saxena (1984) reported that HI has been found to be low in grain legume crops with longer crop growth duration, mainly because of the extended period of vegetative growth. The partitioning efficiency of mung bean (Vigna radiata) $(0.52)$ at maturity (65 DAS) was higher than that of soybean (Glycine max) (0.34) at 72 DAS (Angus et al. 1983). Similar results were reported in maize (Zea mays) (Birch et al. 1999). A similar conclusion can be drawn from plant population densities where plants matured earlier at high populations than at lower populations.

In both seasons $\mathrm{CHI}$ increased as plant population increased up to about twice the optimum. After this level the CHI plateaud. In 1998/99, it increased from 0.43 at one-tenth of the optimum plant population to 0.55 at twice the optimum population, but further increase in plant population to four times the optimum gave no further increase in CHI. This plateau may have been due to the high competition at the highest population for light and nutrients (Ambrose \& Hedley 1984). Also, where plants had the highest competition within the row, there was increased variability in plant size (Weiner et al. 1990). If plant density is sufficiently high, some plants produce pods with no seed and this was a major reason for a low $\mathrm{CHI}$ in peas (Moot 1993). In 1999/2000, the increase in CHI may have been due to the use of uniform, on the square, hand sowing to reduce agronomic variability (Ambrose \& Hedley 1984) and the wetter season (de Costa et al. 1999).

The species $\times$ population interaction indicated that $\mathrm{CHI}$ varied in all four legume species as the population changed. The trend for higher HIs with increased population is similar to results obtained from lentils (Effendi et al. 1989), Vicia faba (Attiya et al. 1983) and lupins (Herbert 1977) in Canterbury. This was due to increased TDM production with a corresponding increase in seed yield (Ashraf et al. 1994). However, in 1998/99, the CHI increased, in all species, between one-tenth of the optimum population and the optimum. Further increases in plant population only produced a further increase in chickpea yield. The highest
CHI (0.62 and 0.63) was observed in chickpea sown at twice the optimum (100 plants $\left./ \mathrm{m}^{2}\right)$ and four times the optimum (200 plants $\left./ \mathrm{m}^{2}\right)$ plant populations. The lack of an increase with increased population in $\mathrm{CHI}$ in the other species may have been due to pod dehiscence at the higher plant populations. Pea pods have been reported to be highly dehiscent (Knott 1987) and loss of seed will affect HI (Owens y de Novoa 1980). However, in a population study with lentil, McKenzie et al. (1986) found that as plant population increased from 100 to 400 plants $/ \mathrm{m}^{2}$ the $\mathrm{CHI}$ declined from 0.33 to $0 \cdot 30$. This reduction or lack of response of CHI to increased population was due to a lack of response of seed yield as there was an attack of Botrytis cinerea on the crop, which curtailed pod filling.

The CHI was consistently positively and strongly correlated $(R>0 \cdot 90)$ with seed yield in all four legume species in both years. Thus the CHI was a good indicator as a selection criterion to improve the yield of these grain legumes by increasing their TDM production.

\section{CONCLUSIONS}

The currently recommended population for chickpeas, lentils, lupins and peas of 50-100, 100-150, 100 and 100 plants $/ \mathrm{m}^{2}$, respectively, do not generally give maximum TDM and seed yield in New Zealand. A sowing depth of $5 \mathrm{~cm}$ appears to be suitable for all four of the legume species tested. Chickpea and narrow-leafed lupin both have the potential to yield more than $6.5 \mathrm{t} / \mathrm{ha}$ of seed in New Zealand. The greater response of chickpea $\mathrm{CHI}$ to plant population was probably due to improved reproductive structure as branching was reduced by increased plant population. Seed yield can be increased by increasing the biological yield without changing the $\mathrm{CHI}$ or by improving the $\mathrm{CHI}$ by partitioning more of assimilates to seed, or by both.

Thanks are due to Dr Derrick Moot for his valuable advice and Laila Ayaz for her help with sample collection. Financial support for Shaukat Ayaz by the New Zealand Vice-Chancellors' Committee is acknowledged.

\section{REFERENCES}

Ambrose, M. J. \& Hedley, C. L. (1984). A population study to aid the selection of improved dried pea (Pisum sativum) crop plants. Annals of Botany 53, 655-662.

Angus, J. F., Hasegawa, S., Hsiao, T. C., Liboon, S. P. \& Zandstra, H. G. (1983). The water balance of postmonsoonal dryland crops. Journal of Agricultural Science, Cambridge 101, 699-710.

Anwar, M. R., McKenzie, B. A. \& Hill, G. D. (1999). Water use efficiency of chickpea (Cicer arietinum L.) cultivars in Canterbury: effect of irrigation and sowing date. Agronomy New Zealand 29, 1-8.

Ashraf, K., Akbar, M. \& Salim, M. (1994). Genetic improvement in physiological traits of rice yield. In Genetic Improvement of Field Crops (Ed. G. A. Slafer), pp. 413-455. New York: Marcel Dekker.

Attiya, H. J., Field, R. J. \& Hill, G. D. (1983). Effect of $\mathrm{PP}_{333}$ and TIBA growth regulators on development and yield components of spring sown field beans (Vicia faba 
L.). Proceedings of the Agronomy Society of New Zealand 13, 81-86.

Ayaz, S., McKenzie, B. A. \& Hill, G. D. (1999). The effect of plant population on dry matter accumulation, yield and yield components of four grain legumes. Agronomy New Zealand 29, 9-15.

Ayaz, S., McKenzie, B. A., Hill, D. G. \& McNeil, D. L. (2004). Variability in yield of four grain legume species in a subhumid temperate environment. II. Yield components. Journal of Agricultural Science, Cambridge 142, 21-28.

Ayaz, S., McKenzie, B. A., McNeil, D. L. \& Hill, G. D. (in press). Light interception and utilization in four grain legume species under different plant populations and depths. Journal of Agricultural Science, Cambridge.

Birch, C. J., Hammer, G. L. \& Rickert, K. G. (1999). Dry matter accumulation and distribution in five cultivars of maize (Zea mays): relationships and procedures for use in crop modelling. Australian Journal of Agricultural Research 50, 513-527.

DAPAAн, H. K. (1997). Environmental influences on the growth, development and yield of pinto beans (Phaseolus vulgaris $L$.). Ph.D. thesis, Lincoln University, Canterbury.

DapaAh, H. K., McKenzie, B. A. \& Hill, G. D. (2000). Influence of sowing date and irrigation on the growth and yield of pinto beans (Phaseolus vulgaris) in a sub-humid temperate environment. Journal of Agricultural Science, Cambridge 134, 33-43.

de Costa, W. A. J. M., Shanmugathasan, K. N. \& Joseph, K. D. S. M. (1999). Physiology of yield determination of mung bean, Vigna radiata (L.) Wilczek under various irrigation regimes in the dry and intermediate zones of Sri Lanka. Field Crops Research 61, 1-12.

Effendi, H., Hill, G. D. \& Field, R. J. (1989). The effect of plant population and growth regulators on growth and yield of lentil (Lens culinaris Medik.) cv. Olympic. Proceedings of the Agronomy Society of New Zealand 19. 25-34.

Erskine, W. \& Goodrich, W. J. (1991). Variability in lentil growth habit. Crop Science 31, 1040-1044.

French, R. J. \& Pritchard, I. (1993). Field pea establishment. In Growing Field Peas (Eds I. Pritchard \& J. Carpenter), p. 38. Perth, Department of Agriculture, Western Australia, Bulletin 4239.

Hardy, A., Huyghe, C. \& Papineau, J. (1996). Light interception efficiency and conversion rate in Andean lupin (Lupinus mutabilis Sweet). In Proceedings of the 8th International Lupin Conference, Asilomar, May 1996 (Ed. G. D. Hill), pp. 22-26. Canterbury, New Zealand: International Lupin Association.

Hedley, C. L. \& Ambrose, M. J. (1981). Designing 'leafless' plants for improving yields of the dried pea crop. Advances in Agronomy 34, 225-277.

Hedley, C. L. \& Ambrose, M. J. (1985). The application of plant physiology to the development of dried pea crop plants. In The Pea Crop - a Basis for Improvement (Eds P. D. Hebblethwaite, M. C. Heath \& T. C. K. Dawkins), pp. 95-104. London: Butterworths.

Herbert, S. J. (1977). Density and irrigation studies in Lupinus albus and Lupins angustifolius. Ph.D. thesis, Lincoln College, University of Canterbury.

Hewitt, A. E. (1992). New Zealand Soil Classification. DSIR Land Resources Scientific Report No. 19. Lower Hutt: DSIR.
Husain, M. M., Hill, G. D. \& Gallagher, J. N. (1988). The response of field beans (Vicia faba L.) to irrigation and sowing date. 1. Yield and yield components. Journal of Agricultural Science, Cambridge 111, 221-232.

KnotT, C. M. (1987). A key for stages of development of the pea (Pisum sativum). Annals of Applied Biology 111, 233-245.

Ma, Q., Longnecker, N., Emery, N. \& Atkins, C. (1998). Growth and yield in Lupinus angustifolius are depressed by early transient nitrogen deficiency. Australian Journal of Agricultural Research 49, 811-819.

McKenzie, B. A. \& HILL, G. D. (1991). Intercepted radiation and yield of lentils (Lens culinaris Medik.) in Canterbury New Zealand. Journal of Agricultural Science, Cambridge 117, 339-346.

McKenzie, B. A. \& Hill, G. D. (1995). Growth and yield of two chickpeas (Cicer arietinum L.) varieties in Canterbury, New Zealand. New Zealand Journal of Crop and Horticultural Science 23, 467-474.

McKenzie, B. A., Hill, G. D., White, J. G. H., Meijer, G., Sikken, G., Nieuwenhuyse, A. \& Kausar, A. G. (1986). The effect of sowing date and population on yield of lentils (Lens culinaris Medik). Proceedings of the Agronomy Society of New Zealand 16, 29-33.

McKenzie, B. A., Miller, M. E. \& Hill, G. D. (1989). The relationship between lentil crop population and weed biomass production in Canterbury. Proceedings of the Agronomy Society of New Zealand 19, 11-16.

Моот, D. J. (1993). Harvest index variability within and between field pea (Pisum sativum L.) crops. Ph.D. thesis, Lincoln University, Canterbury.

Моот, D. J. (1997). Theoretical analysis of yield of field pea (Pisum sativum L.) crops using frequency distributions for individual plant performance. Annals of Botany 79, 429-437.

Moot, D. J. \& McNeil, D. L. (1995). Yield components, harvest index and plant type in relation to yield differences in field pea genotypes. Euphytica 86, 31-40.

OMAR, M. \& S INGH, K. B. (1997). Increasing seed yield in chickpea by increasing biomass yield. International Chickpea and Pigeonpea Newsletter 4, 14.

OWens y. DE NovoA, C. (1980). The effect of plant arrangement and population on the growth and seed yield of Phaseolus vulgaris $c v$. Salinac. M.Agr.Sc. thesis, Lincoln College, University of Canterbury.

Parvez, A. Q., Gardner, F. P. \& Boote, K. J. (1989). Determinate and indeterminate-type soybean cultivar responses to pattern, density, and planting date. Crop Science 29, $150-157$.

Pilbeam, C. J., Hebblethwaite, P. D., Ricketts, H. E. \& Nyongesa, T. E. (1991). Effects of plant population density on determinate and indeterminate forms of winter field beans (Vicia faba). I. Yield and yield components. Journal of Agricultural Science, Cambridge 116, 375-383.

Saxena, M. C. (1984). Agronomic studies on winter chickpea. In Proceedings of the Workshop on Ascochyta and Winter Sowing of Chickpea, Aleppo 4-7 May 1981 (Eds M. C. Saxena \& K. B. Singh), pp. 123-137. The Hague, Netherlands: Junk Publishers.

SAXENA, M. C. (1987). Agronomy of chickpea. In The Chickpea (Eds M. C. Saxena \& K. B. Singh), pp. 207-232. Wallingford: CAB International. 
Saxena, M. C. \& Goldsworthy, P. R. (1988). Research on cool season food legumes at the International Centre for Agricultural Research in the Dry Areas (ICARDA). In World Crops: Cool Season Food Legumes (Ed. R. J. Summerfield), pp. 25-37. Dordrecht, The Netherlands: Kluwer Academic Publishers.

Siddique, K. H. M. \& Loss, S. P. (1999). Studies on sowing depth for chickpea (Cicer arietinum L.), faba bean (Vicia faba L.) and lentil (Lens culinaris Medik), in a Mediterranean-type environment of south-western Australia. Journal Agronomy and Crop Science 182, 105-112.

Siddique, K. H. M., Walton, G. H. \& Seymour, M. (1993). A comparison of seed yields of winter grain legumes in Western Australia. Australian Journal of Experimental Agriculture 33, 915-922.

Siddique, K. H. M., Loss, S. P., Regan, K. L. \& Jettner, R. L. (1999). Adaptation and seed yield of cool season grain legumes in a Mediterranean environment of south-western Australia. Australian Journal of Agricultural Research 50, 375-387.

Silim, S. N., Saxena, M. C. \& Erskine, W. (1990). Seeding density and row spacing for lentils in rainfed Mediterranean environments. Agronomy Journal 82, 927-930.

Stanforth, A., Sprent, J. I., Brockwell, J. \& Beck, D. P. (1994). Biological nitrogen fixation: basic advances and persistent agronomic constraints. In Expanding the Pro- duction and Use of Cool Season Food Legumes (Eds F. J. Muehlbauer \& W. J. Kaiser), pp. 821-831. Dordrecht, The Netherlands: Kluwer Academic Publishers.

Stern, W. R. (1965). The effect of density on the performance of individual plants in subterranean clover swards. Australian Journal of Agricultural Research 16, 541-555.

STUCKY, D. J. (1976). Effect of planting depth, temperature, and cultivars on emergence and yield of double cropped soybean. Agronomy Journal 68, 291-294.

Thomson, B. D., Siddique, K. H. M., Barr, M. D. \& WiLson, J. M. (1997). Grain legume species in low rainfall Mediterranean-type environments. I. Phenology and seed yield. Field Crops Research 54, 173-187.

Vellasamy, G., Hill, G. D. \& McKenzie, B. A. (2000). The advantage of lupins in crop rotations in New Zealand. In Proceedings of the 9th International Lupin Conference, Klink-Müritz, June 1999 (Eds E. van Santen, M. Wink, S. Weissmann \& P. Roemer), pp. 187-192. Canterbury, New Zealand: International Lupin Association.

Wangdi, K., McKenzie, B. A. \& Hill, G. D. (1990). Field establishment of Russell lupin. Proceedings of the Agronomy Society of New Zealand 20, 29-36.

Weiner, J., Mallory, E. B. \& Kennedy, C. (1990). Growth and variability in crowded and uncrowded populations of dwarf marigolds (Tagetes patula). Annals of Botany $\mathbf{6 5}$, $513-524$. 